\title{
A NEW POPULAR FRONT, OR, ON THE ROLE OF CRITICAL JURISPRUDENCE UNDER NEO-AUTHORITARIANISM IN CENTRAL-EASTERN EUROPE
}

\begin{abstract}
The current decade brought a neo-authoritarian wave to the countries in CEE. This process, which in certain respects runs parallel to the populist upsurge in Western countries, has its own specificity. Firstly, by focusing on the clash between "elites" and "the people", it rekindles - in a displaced, right-wing form - the class conflict which before 1989 was an ideological staple in CEE countries. Secondly, insofar as neo-authoritarianism in CEE has often a distinctly neo-liberal agenda shadowed by declarative anti-globalism and national chauvinism, it warps the field of political struggle. Thirdly, in the neo-authoritarian turn law becomes the crucial field of ideological fight, principally in those countries where populists came to power. In this respect, new governments in CEE resort to a blend of old Fascist tools (such as dismantling of constitutional control and denying the primacy of international law) and new inventions (such as the effective state of exception in some areas of law in Poland introduced in 2015-18). The role of critical jurisprudence in CEE is therefore particularly significant and difficult. The paper argues that liberal jurisprudence, although actively engaged in analysing neo-authoritarianism, does not possess adequate conceptual tools for full success. Therefore critical jurisprudence should urgently take part in explaining neoauthoritarianism in the legal field.
\end{abstract}

Keywords: neo-authoritarianism, constitutional crisis, rule of law, critical jurisprudence, populism.

Critical jurisprudence usually portrays the legal universum in dark colours, and quite rightly so. Nevertheless, there are times when a yet darker hue of black begins to dominate and the cause of freedom begins to lose. For all critical thinking - at least the current which harks back to Marx and inherits from the Frankfurt School - such historical moments present an uncanny challenge. The eye which is well adapted to black might be less inclined to notice that the twilight is moving forward surprisingly fast. It is rather liberal jurisprudence that seems to take account of slowly progressing tectonic rifts that, once completed, will separate us for good (and bad) from the world in which critical jurisprudence flourished. Suddenly, what the Crits denounce as a bare play of interests and power under the hegemonic and neutralised edifice of positive law is brought to light. The liberal disguise begins to lose its mystifying force and the critical discourse is confronted with movements or governments that machiavellianly abuse legal

\footnotetext{
"Jagiellonian University, przemyslaw.tacik@uj.edu.pl
} 
instruments. Given that these historical periods are times of great confusion, they require - especially from the critical jurisprudence (and, generally speaking, all critical approach) a careful calculus of one's own positions. It is only in this manner that divisions between the critique and the criticised may be re-drawn.

This paper is meant to argue that processes of degradation of the rule of law, the rise of nationalism and authoritarianism - variously defined and having multiple forms - should be viewed as signs of an epochal challenge not only for liberal, but also for critical jurisprudence. In Central-Eastern Europe, with its own complex legal history, legacy of real socialism, relations of post-colonial dependence from the West and impact of turbo-capitalist transition - and, most importantly, with most crystal examples of turning to new forms of semiauthoritarian regimes that might be found within the EU - critical jurisprudence must promptly reconsider its own strategies.

This change comes in a somewhat unfortunate moment, given that critical legal studies in this part of Europe only recently began to gain its own voice and perspective (Mańko, Cercel, Sulikowski 2016, 1-11). Critical jurisprudence has so far focused more on the legacy of real socialism and the (neo-)liberal hegemony in post-socialist countries of CEE, simultaneously struggling for recognition in the Western academia. Therefore the confrontation with the ongoing authoritarian turn might require speedy adaptation processes and developing new intellectual tools. Nevertheless, deliberate myopia for the recent events, or even a kind of Schadenfreude on the part of the CEE Crits in times of populism would not augur well for self-criticism and self-orientation of critical jurisprudence. That the liberal opponent has been weakened is obviously an opportunity for better dismantling of previously hegemonic ideological veil, but it runs the risk of contributing to the right-wing authoritarian assault on values that the critical movement should not dispense with, such as personal and civic freedoms, gender and LGBTQ+ equality, rights of minorities as well as egalitarianism abstracting from nationality or ethnicity. In other words, critical jurisprudence is in dire need of outlining a third way - not in the compromised sense connoting the debacle of the left in the 90 s, but understood as a position from which liberal ideological hegemony might be criticised on a par with anti-emancipatory populist movements which openly rekindle spectres of thick nationalism.

The paper consists of four parts. Firstly, it attempts to outline what the neoauthoritarian transformation is, especially in the context of CEE on the example of Poland and Hungary. Then it proceeds to investigating the strained relationship between CEE neo-authoritarianisms and the law. The third part provides a brief overview of liberal jurisprudence in its attempts to grasp and criticise neoauthoritarianism as a practice openly challenging the rule of law. Finally, it aims to provide a few orientation points concerning the desired position and tasks of the CLS in the context of CEE neo-authoritarianism. 


\section{THE NEO-AUTHORITARIAN TURN IN THE CENTRAL-EUROPEAN CONTEXT}

The predicament with naming the processes which we are currently witnessing is well known and habitually deplored: terms such as "populism", "authoritarianism", "neo-authoritarianism" or "illiberal democracy" are usually used as conventional references (Pech, Scheppele 2017, 4). Given that the designates remain more or less the same, the process is not fully intelligible (especially in its long-term consequences) and all the names seem somewhat trite or worn out, they should be used more as provisional stickers rather than ossified naming conventions. Instead of musing on whether "populism" is an operationalisable tool or whether "illiberal democracy" is still a democracy, I would opt for choosing one of the terms as (at least transiently) more pertinent than others: neo-authoritarianism.

I borrow it from Polish sociologist Maciej Gdula who in his otherwise debatable enquiry into the rise of Poland's far-right government meant to highlight that it is supported not (chiefly) because of its pro-social agenda and unblocking the previous neo-liberal consensus on a class-biased austerity, but due to the component of public revenge on the elites, broadly perceived by some strata of Polish society as corrupt, hegemonic and unjust (Gdula 2018). As Gdula argues, Poland's ruling majority produces a spectacle of vengeance and humiliation on institutions, authorities and individuals who were anyhow prominent under the previous government. Adherents of the far-right coalition may thus identify their own perception of injustice or underprivileged status with the Debordian spectacle in the public sphere. In this sense, "neo-authoritarianism" grasps well the mechanism of mobilising the general disenchantment with globalisation and liberal democracy which is channelled into a movement against an enemy constructed with far-right imagery.

Apart from this explanatory power, "neo-authoritarianism" might be linked to a few further connotations which can make it a handy conceptual tool for analysing the recent developments in CEE: (1) it retains the component of authoritarian rule, even if variously squared with elements of Western liberal democracy, (2) it underlines a certain continuity of pre-War and post-War right/ far-right politics as centred on coerced unanimity of opinions, normalisation of support for the ruling power, arbitrariness, anti-minority rhetoric and policies, rekindling nationalism and the foe-friend division, (3) it points to a transformation of socio-political context in which this new form of authoritarianism functions, (4) it catches the elusive presence of past forms of far-right governments, the one which Neil Levi and Michael Rothberg called "the mnemonic flash of fascism" (Levi, Rothberg 2018, 356) and, finally, (5) it is undetermined enough to provide a working tool for referring to the still unfinished processes. 
Applying this concept to the context of Central-Eastern Europe in order to orientate critical jurisprudence requires finding some basic coordinates of this region's specificity. Naturally, CEE neo-authoritarianism, if we settle for this term, bears similarities to processes which happen throughout the contemporary world with most crystal examples in "trumpism" or Rodrigo Duterte's rule in the Philippines. Western Europe has equally produced analogous movements, led by Marine Le Pen in France, Geert Wilders in the Netherlands or Matteo Salvini in Italy. In the field of political studies, there are already some valuable preliminary analyses of the new kinds of populism (Müller 2016, Moffitt 2016, Saward 2010). All these phenomena can be understood only with reference to some elementary socio-political conditions such as: (1) transformations of the public sphere by the Internet and the subsequent democratisation and fragmentation of knowledge (which, on the one hand, allow of consolidation of movements on the basis of beliefs excluded or non-represented in the official channels of communication, and, on the other hand, prevent systematic verification of news, thus contributing to spread of conspiracy theories as well as incoherent and ideologically biased opinions), (2) post-neoliberal intellectual desert, in which in-depth analysis of the current conditions is hampered by most mystifying ideological misrepresentations; in a supremely Baudrillardean way, the ideological seems nowadays greatly displaced in comparison with actual social relations, making politics be reigned by drifting simulacra, (3) the unprecedented historical collapse of the left on many levels: intellectual (lack of general theory of world/state justice and absence of proper political agenda stemming from it), political (the left is now divided between waning social-democratic parties of the old establishment - still too strong to disappear, but too weak to hold power and bring about a significant change - and new movements, still struggling for self-definition and broader recognition) and organisational. Nonetheless, there are some significant factors that differentiate neo-authoritarianism in CEE from its Western or global counterparts.

First of all, the most notable difference consists in the fact that unlike Western Europe CEE has witnessed the rise of far-right populist movements gaining power and establishing governments which in the last few years have undertaken vast transformations of the previous liberal regimes. Naturally, the rise of Austrian (far-)right-wing majority (comprising the infamous FPÖ party) or the recent actions of the Italian Lega are also reminiscent of "illiberal democracies" (and might lead to building them in the future), yet it is only in CEE that these neoauthoritarian regimes are actually constructed (cf. Bugaric, Kuhelj 2018, 22). The difference is most visible at the legal level. Both Hungary and Poland, which are the basic examples, underwent a significant change in the relation between power and law: law is treated at best instrumentally, with permanent attacking the bulwarks of the rule of law standards and sometimes, especially in the case of Poland, the very applicability of law is dismantled. 
Secondly, CEE democracies even before the neo-authoritarian turn were - in liberal terms - classified as "flawed" democracies (The Economist Intelligence Unit's 2018). The accumulated historical burden of long-term peripherality, real socialism and brutal transition to market economy determined the adaptation of liberal democracy. Moreover, these countries are marked by relatively high levels of nationalism (cf. Bugaric, Kuhelj 2018, 23, 26-27) - with still unworked-through legacy of nationalism cultivated by popular democracies. This entanglement at least partially accounts for the particular blend of socialist measures and chauvinistic rhetoric that marks neo-authoritarian governments in this region. The legacy of real socialism and swift transition to neoliberalism also contributed to increasing the "post-ideological" desert in these countries. With low levels of intellectual culture and lack of competent organic intellectuals (in the Gramscian sense), CEE states are particularly prone to ideological misrepresentations with conspiracy theories elevated to the rank of officially endorsed beliefs (like George Soros' alleged influences on Hungarian institutions and opposition or Polish myth of "communist deposits" who paralyse the country's development).

Finally, neo-authoritarianism in CEE must be read in postcolonial context. These countries, historically suspended in almost perpetual dependence and, worse enough, having some cultural propensities to dependence-centred perception of the world, are now once again in the peripheries, this time of the EU. In economic terms, they are dependent on the Western core of the Union, which is particularly manifest in the relationship between Poland and Germany. Dependence reproduces itself on many levels; on the personal plane, many citizens of CEE countries (especially of Poland and Romania) have experienced economic migration to the West and relative deprivation.

Taking into account this specific context of CEE countries, neoauthoritarianism might be seen as a conceptual tool which is much more explanatory in relation to them than to states of Western Europe or nonEuropean ones. The term accentuates a peculiar blend of continuity and novelty which accounts for their current far-right deviations. Unlike Western Europe, neo-authoritarianism has two legacies that it draws from (although with only implicit references): the experience of socialist autocracy and the practice of nonnegotiable neoliberal governing as a condition of possibility of politics, beyond actual representations of the political agon. Critical jurisprudence is usually well acquainted with legal weaponry of the latter, whereas long legal and political shadow of the former - especially inasmuch as it contributed to producing a properly nationalistic imagery of homogenous nations, protected by states against external threats - is less recognised.

If, however, critical jurisprudence is to provide a pertinent and original answer to CEE neo-authoritarianism, it needs to undertake a systematic review of its origins, practices and ideology in relation to both previous types of authoritarianism. As far as the legacy of "technical" authoritarianism of liberal 
capitalism is concerned, it seems that to all intents and purposes the current neo-authoritarian governments in CEE not only have not ruptured with it, but continue to use its paradoxical strategy of building "democracy without a choice". Their purportedly socialist measures, especially in Poland (such as the "500+ programme", consisting in benefits for families or introducing a minimum wage for workers employed on civil contracts) do not form part of a well-constructed, comprehensive and just socialist agenda. They are, moreover, accompanied by purely neoliberal practice in pro-capitalist politics. As a result, the class conflict is exploited in an extremely misrepresented manner.

In this regard, the current developments also need to be seen in the light of the wane of the language of class struggle under late real socialism and its almost absolute evaporation in CEE after the fall of the Iron Curtain. In a displacement which bears many affinities with classic manoeuvres of fascism, the class struggle has been diverted to construct a chain of equivalence between imaginary class enemies (essentially, all the "elites" which do not support the far-right governments, especially judicial and cultural ones) and usual scapegoats (Jews - although referred to via crypto-anti-Semitic language of understatements and suggestions - Muslims, refugees and ethnic minorities). Therefore the CEE neoauthoritarianism must be seen in the light of a massive social misrepresentation of the class struggle, centred on authoritarian tendencies and ideology of pure power. In this regard, all tools offered by previous dysfunctional liberal democracies are used to pursue quite a universal neoliberal agenda under the official guise of anti-globalism and anti-Europeanism. It is for this reason that the clash between Hungary and Poland and the EU is hardly concentrated on economic matters, but on standards of democracy (space for opposition, rule of law, independent judiciary etc.) and human rights protection, even though neo-authoritarian governments sap energy from class conflict displaced by globalisation.

\section{LAW AS A FIELD OF FIGHT}

Not unexpectedly, law becomes a crucial field of expansion of neoauthoritarianism and it is in this area that its clash with broadly conceived liberal democracy comes to the fore. Both CEE examples of neo-authoritarian governments, the Hungarian and the Polish one, brought about a profound transformation of legal systems in both countries, although in each case they resorted to different strategies. The Orbán government seized the opportunity of gaining constitutional majority (as a result of low demands that the previous constitution stipulated for its amendment and a pro-majority electoral rules) and openly undertook a systematic overhaul of Hungarian legislation, beginning with adopting the new constitution in 2011. The far-right government in Poland did not share its ally's luck and, without constitutional majority, must have taken an even 
more unsettling path. The combination of gaining sway over key institutions (the public prosecution, the Constitutional Court, the National Council of Radio and TV, the National Council of the Judiciary and, work still in progress, the Supreme Court and common courts) and amending the constitution with sub-constitutional laws made it possible to gain direct control over a huge part of state apparatus and legal norms.

The two strategies are manifestly different, but mainly in two points. Firstly, they differ in their ideological effects. The new Hungarian constitution was adopted as a blatant contestation of liberal ideals of democracy; it is based on strong nationalistic rhetoric and a vision of the nation as ethnos, not demos. Poland, however, is still formally ruled by its 1997 liberal constitution, although it became practically inapplicable to a high degree. As a result, the Polish farright transformation could not be satisfied with finding its "ultimate expression" in an appropriate basic law. The overall direction of this transformation has not been sanctified in any legal manifesto, which increases the rift between audacious anti-European chauvinist rhetoric of the ruling majority and its down-to-earth instrumental approach to the law and the state. Secondly, Hungary preserved to a much higher extent the form of legality and the very applicability of the opposition "legal/illegal", whereas Polish legal system in some of its parts becomes inoperable, because state institutions may - according to their current political affiliation - apply either non-constitutional laws or the Constitution itself. If there is no institution which can declare illegality in a legitimate manner (as the Constitutional Court in its current formation is unconstitutional itself), the opposition legal/illegal loses its positive objectivity. For this reason the current legal system in Poland constitutes a real challenge for jurisprudence which needs to find better conceptual tools than just sticking to explaining why and in which respect the majority's manoeuvres violate the constitutional legal order.

Despite these crucial differences between the two CEE neo-authoritarian governments, practical effects of their actions are often quite convergent. They concentrate on gaining pure, possibly unbridled power, whereas law is at best just an instrument to exercise it (cf. Scheppele 2015, 124). Nevertheless, given that both countries still formally pledge allegiance to the Western world and the EU (even if mingled with anti-European and anti-liberal rhetoric), they seem to feel still obliged to maintain the mask of liberal democracies. In this manner, they evolve into what Gábor Halmai called "hybrid regimes" (Halmai 2014, 512). Formally, they retain the recognisable institutional framework of liberal regimes, yet the executive (having dominated the legislative and effectively depoliticising it - cf. Ágh 2017, 20) either gained full control over the institutions that ought to be independent - thereby making their existence senseless - or marginalised them to such a degree that they cannot be of any hamper. The handover of the Polish Constitutional Court is a good example of the first strategy, whereas the Fourth Amendment to the Hungarian 2011 Constitution - inasmuch as it 
effectively deprived the Hungarian CC of its institutional memory and continuity of interpretation (Halmai 2014, 500-501; Sólyom 2015, 27-30) - proves efficiency of the latter.

All in all, the CEE neo-authoritarianism demonstrates a complex approach to law, which might be viewed in its short- and long-term consequences, as well as depth of interference with the legal system. As far as short-term consequences are concerned, both Hungary's and Poland's legal systems are field of struggle between the liberal and the neo-authoritarian sides. The latter aim to demonstrate violations of the Constitution or of international and EU law or their standards, as well as to retain as much as possible from the framework of liberal democracy (cf. the role of the Polish ombudsman). The former approach the legal system as a field that needs to be conquered with intra-legal, extra-legal and preater-legal methods.

Long-term consequences, however, are more difficult to assess, especially in case of Poland. The institutions whose members were appointed illegally already act and their decisions will shape legal relationships. Each day the legal chaos is increasing, as non-constitutional laws which cannot be declared as such by the paralysed CC envisage non-constitutional regulations of institutions (especially of courts) which, on their part, adjudicate. Numerous tricks undertaken in Poland and Hungary defy the elementary division between legality and illegality: power is exercised by non-recognition of valid acts of legal institutions by other institutions controlled by the ruling majorities. In this respect the very coherence of the legal system is undermined. Moreover, as in past historical examples (it is enough to remind oneself of Hitler's obsessive attacks on lawyers and jurisprudence - Broszat 1969, 130ff), the law in itself is presented as an obstacle than prevents the almost total imaginary overlap between the will of the people, as represented by populist governments, and the state machinery. This rhetoric profoundly affects the social perception and ideology of the legal field. It seems clear now that even in the case of quite improbable return of liberal forces the legacy of neo-authoritarian manoeuvres will last long.

As far as short-term consequences are concerned, liberal jurisprudence has done a lot of good work in raising awareness about the ongoing changes. Nevertheless, it seems quite unprepared to grasp their deep effects on legal systems, legal culture and the interface between the political and the legal in neoauthoritarian CEE countries.

\section{LIBERAL JURISPRUDENCE AGAINST NEO-AUTHORITARIAN ILLEGALITY}

Even if with somewhat lingering at the beginning, liberal jurisprudence - not only from CEE, but from Western Europe and the US as well - is now in full swing in denouncing the transformations in Hungary and Poland. The literature on the topic is already quite vast. Given that this article does not aim to describe 
the ongoing debate in full detail, it must be enough to observe a few major trends in how CEE neo-authoritarianism is analysed.

First of all, perhaps since the establishment of the liberal consensus after the fall of the Iron Curtain liberal jurisprudence has not known such an irruption of the political into the legal as it witnesses now (cf. Palombella 2018, 8). Nolens volens the analysis of neo-authoritarianism in the legal field calls into question the uneasy relationship between the legal and the political, so even if the latter is sometimes filtered through a rather unsophisticated conceptual grid (with a notable overuse of the concept of populism), it is seen as an unobvious underlining of law which no longer can be contained by constitutional rules.

Unsurprisingly, the notion which guides a vast majority of analyses is the concept of the rule of law. Applied against the background of the challenge that CEE neo-authoritarianism presents to it, it seems to best capture the surface of the liberal/anti-liberal rift. The upsurge of anti-liberal rhetoric and measures gave an impulse for re-considering what the rule of law means today. Some commentators are aware of the paradox that liberal nation-state necessarily produces: radical democratic demand might lead to "democraduras" if not curbed by the rule of law (Palombella 2018, 9-10). In this line, the rule of law should be viewed rather as "the way legality is organised by also allowing a side of positive law capable of a contrasting and resisting autonomy vis-à-vis the laws issued by those in power" (Palombella 2018, 10). Usual ideals of non-arbitrariness and Fullerian demand of predictability are also invoked, which seems of high pertinence in times when the Polish and Hungarian governments might almost overnight change each law against any standard of continuity and envisageability.

Nevertheless, the rule of law is seldom investigated at its conceptual roots (Pech, Scheppele 2017, 9-10). Only Gianluigi Palombella overcomes the simplistic view of the EU's defence of the rule of law, demonstrating that the EU's account in this regard is not that favourable, whereas the crisis it faces calls into question the very relationship between the will of the people and law generation (Palombella 2018, 15-17). Commentators notice how the rule of law - enmeshed in a thick web of international and EU law and cooperation between different levels of governance - is being openly contested in the name of national sovereignty (Ágh 2017, 25; Halmai 2014, 510). In this respect, liberal commentators abstract from a notoriously paradoxical nexus between national sovereignty and international law, settling for noticing that neo-authoritarian regimes blatantly contest the former in the name of the latter.

The notion of populism is a usual key to explaining relationship between the political and the legal. The two decades between 1990 and 2010, in themselves uneasy for standards of liberal democracy in CEE, are now deplored as times of "mild populism" (Ágh 2017, 8, 17) which did not undermine the very ideological framework of what is politically desirable. Even if some sins were committed, the Big Other was never challenged. Now, however, populism seems to attack the 
very roots of modern liberal states. As to the causes of the current predicament, the socio-economic ground is usually acknowledged, often without much further enquiry, with scarce notable exceptions (Ágh 2017, 8ff). Rise of nationalism and identity politics is also observed (Ágh 2017, 9). Quite often commentators refer to the transformation of the public sphere under the influence of new forms of communication (Ágh 2017, 9).

As far as CEE countries are concerned, commentators often notice superficial adoption of Western standards in the aftermath of 1989. The cultural and civilisational aspect of flawed democratisation (or Europeanisation) seems to come to the fore (Halmai 2014, 513). Attila Ágh presents the pre-neo-authoritarian era in CEE as times of reciprocal mimicry between CEE countries and the EU: the former dressed up their "historical deficits" in garb of successful progress with only tiny glitches, whereas the latter took their declarations at face value without offering an adequate response to their civilisational backwardness (Ágh 2017, 13-14, 16-17). As a result, the marriage between the EU and CEE countries seems a rather unmatched one, with both sides culturally unprepared for each other. CEE countries are perceived as lacking "democratic resilience" (Ágh 2017, 18). Such a state might be even contributed to by the EU as long as local autocrats are allies of political parties at the EU level (Kelemen 2017, 231). Mass support for the Hungarian Fidesz or the Polish Law and Justice - unabating despite international criticism - are a major source of concern, presented sometimes as an inexplicable misery that might augur a permanent decline of liberal democracy in CEE (cf. Oliver, Stefanelli 2016, 1080; Palombella 2018, 6).

Weaknesses of the EU are a subject in itself. Its legitimacy is now perceived as heavily burdened by inadequate responses to the economic crisis, bureaucratic isolation, lack of direct democratic control over its institutions (especially in comparison with the populist short circuit between imaginary people's will and its exercise over state apparatus) as well as a clear pro-market bias (Ágh 2017, 10-12; Pinelli 2011, 15). According to some voices, integration through law - a naked emperor whose symbolic clothes were for long venerated as a peaceful and "apolitical" method of building the Union - has now been revealed in the form of populist backlash it sparked off by its elitist and undemocratic character (Scharpf 2015). On the other hand, lack of advancements in integration is also criticised for contributing to neo-authoritarianism. As R. Daniel Kelemen put it, the EU constitutes now "an «authoritarian equilibrium», with just enough partisan politics at the EU level to coddle local autocrats, but not enough to topple them" (Kelemen 2017, 214). Some commentators engage in unmasking the effective state of exception which in the crisis years was practiced in the EU governance and can no longer be tacitly accepted under the guise of normalcy of integration (Joerges, Kreuder-Sonnen 2017, 121, 127).

Liberal commentators often severely criticise the EU for its paralysis before the Medusa gaze of neo-authoritarianism. They point to its indecision, 
counter-productive measures, lingering and lack of adequate legal tools against anti-liberal populism (Pech and Scheppele 2017, 13-24, 28-34; Ágh 2017, 21-25). Reluctance to re-adapt available legal devices and inefficiency in the EC's actions are also noted (Oliver and Stefanelli 2016, 1076-1080; Kelemen 2017, 225). Some commentators point to the fact that violating the rule of law coupled with the principle of mutual trust in the EU might entail problems also for countries not affected by neo-authoritarianism (Bonelli 2018, 49-53; Pech and Scheppele 2017, $7,11)$.

As far as answers to the current predicament are concerned, the opinions are divergent and rather pessimistic. Some authors engage in conceiving effective legal devices of EU law that could curb neo-authoritarian governments - from the famous Heidelberg "reverse Solange" proposal, through budget pressure (Pech, Scheppele 2017, 45) up to Scheppele's "systemic infringement procedure" (Bonelli 2018, 57-63; Pech, Scheppele 2017, 35-38). Others perceive them as hardly feasible and suggest modest focusing on the already functioning institutions, mainly on Art. 7 TEU (Pech, Scheppele 2017, 7; Bonelli 2018, 63-65), or call for actions of liberal Member States (Pech, Scheppele 2017, 26).

All in all, since a long time, if ever, liberal jurisprudence - especially in the field of European studies - has not been confronted with such a challenge. The liberal compromise has been clearly shattered: the debris of its fall keep spreading and cannot be ignored by the doctrine of EU law. Its entanglement in all-too-easy eulogy for integration regardless of the means used has already drawn substantiated criticism (Joerges, Kreuder-Sonnen 2017, 120-138). Nevertheless, liberal analyses of neo-authoritarianism - despite the sophistication of some of them - often have a few lacunas which need to be confronted by critical jurisprudence.

\section{NEO-AUTHORITARIANISM AND CRITICAL JURISPRUDENCE}

Critical jurisprudence in Europe and especially in CEE is now confronted with a challenge of probably epochal character. On the one hand, it is itself put in an uneasy position: in a sense, it sees it dream coming true in a perversely warped way. Neo-authoritarian governments bring back the dimension of the political and very often use the rhetoric that harks back to critical approaches to liberal ideology of apolitical rule of law. It was well visible in the case of the Polish CC, which was attacked quite along the lines of previous critical analyses (cf. Sulikowski 2012), although to instrumental reasons. Yet just as fascism might be read as a perverted emancipatory struggle, so does this critique has no goals that the Crits aspire to. Nevertheless, the CLS must clearly draw the line between its approach and the manipulative, rightist and nationalist misuse of its heritage. It is not easy to find the correct side of the antagonism, but in 
my opinion no alliance with neo-authoritarianism is a boundary condition for all sensible critique. I would argue that in this struggle the Crits must recognise that they belong to the camp of the Enlightenment, together with liberals. At the same time, all kinds of collusion between neo-authoritarianisms and the liberal side should be vigorously denounced. We can see it clearly in the case of the EU: the unholy alliance between neo-authoritarian governments and EU establishment (the EPP-Fidesz cooperation, ritual "dialogue" carried out by the EC, tacit sympathy of some governments, i.e. Austrian and Italian ones, for CEE neo-authoritarianisms) is a cause of worry even for liberal doctrine; all the more vehemently should it be decried by the CLS. From the part of academia, liberal normalisation of neoauthoritarianism or even granting to its inventions a place in the European legal area requires polemical response.

In the field of jurisprudence the ossified liberal consensus seems to crumble and debate has been opened. As the two sides are now well entrenched in their camps, the voice of the left - always the uneasy third party - is hardly hearable. The CLS in CEE is relatively new, still occupied with ensconcing itself in the academic milieu and re-appropriating conclusions of earlier Western debates. Nonetheless, direct intervention in the current struggles within the field of jurisprudence is nowadays acutely needed. Neo-authoritarianism will not be conquered by eulogising the rule of law and denouncing its dismantlement. Critical jurisprudence needs to bring in its own apparatus, supplementing those areas in which liberal doctrine remains mute.

What are they? The above-mentioned review of literature demonstrated that mainstream jurisprudence is already able to open the debate of the relationship between the legal and the political or to reconsider - at least to a certain extent - the pernicious effects of previously hegemonic uncritical approach to liberal dogmas. It is, however, much worse at seven main intellectual and practical challenges: (1) re-evaluating the causes of neo-authoritarianism beyond the scheme of assault on liberal democracy by demagogues exploiting uneducated masses, (2) understanding continuity between neo-authoritarianism and earlier forms of monopolised power, such as nationalist stages of real socialism regimes and early liberal technocratic governments, (3) analysing in-depth long-term effects of neoauthoritarian changes, (4) reassessing the fundamental values of the legal system, such as predictability, reasonability and certainty in order to save them from the crumbling liberal dogma, (5) reinventing ways out of the crisis, (6) redesigning the new legal foundations of democracy, which would be both non-exclusive and resilient to far-right handover and finally (7) reinventing the very construction of EU law - and new models of integration - which would be able both to adequately address the challenge of right-wing populism and take responsibility for social costs engendered by capitalism (see Azmanova 2013, 33-34).

The most crystal example of conceptual framework that the CLS could bring into the current debate is the post-Agambenian notion of the state of exception. It is 
more than ever adaptable to explaining hybrid regimes which construct autocracy in the garb of allegedly democratic forms. In the case of Poland, which is more conceptually challenging, it might be the principal conceptual tool to describe how the hitherto coherent legal system composed of acts and institutions that recognised themselves mutually was disrupted by refusals to recognise the validity of norms or acts by executive-controlled institutions. The relationship between the legal system and its outside, re-absorbed into play by neo-authoritarianism, needs to be portrayed adequately with the concept of the state of exception.

\section{CONCLUSIONS: THE URGENT NEED FOR CLS}

In analysing the current wave of neo-authoritarianism liberal jurisprudence cannot reach the necessary depth: the conceptual framework that the CLS might elaborate is acutely needed. Contrary to what might appear at first glance, the CEE neo-authoritarianisms do not tend towards suspending the law in order to exercise pure power (which is how Nicos Poulatzas interpreted fascism - cf. Poulantzas 1979, 322), but rather produce complex hybrid regimes which intermingle norms of different origin (supranational and national) with a grid of exceptions clouding the power of the executive. In this sense, they are a direct continuation of technocratic liberal democracies, developing their façade techniques of governance. That neo-authoritarian countries might still be functioning members of the EU points to a critical short circuit between the liberal blank point and the new far-right governmentality.

On the conceptual level, I argue, the CLS should therefore directly and urgently engage in analysing the ongoing change in CEE jurisprudence. On the political level, however, it should join the liberal side in defending fundamental values and post-Enlightenment legacy in a kind of tactical popular front. Nonetheless, it can never lose from its sight the opportunities created by the irruption of the political into the field of mainstream jurisprudence.

\section{BIBLIOGRAPHY}

Ágh, Attila. 2017. "The EU Polycrisis and Hard Populism in East-Central Europe: From the Copenhagen Dilemma to the Juncker Paradox". Politics in Central Europe 13(2/3): 7-32.

Azmanova, Albena. 2013. "The Crisis of Europe: Democratic Deficit and Eroding Sovereignty - Not Guilty". Law and Critique 24: 23-38.

Bonelli, Matteo. 2018. "A Federal Turn? The European Union's Response to Constitutional Crises in the Member States". Perspectives on Liberalism 10(1): 41-70.

Broszat, Martin. 1969. Der Staat Hitlers: Grundlegung und Entwicklung seiner inneren Verfassung. München: Deutscher Taschenbuch Verlag.

Bugaric, Bojan. Alenka Kuhelj. 2018. "Varieties of Populism in Europe: Is the Rule of Law in Danger?" Hague Journal of the Rule of Law 10: 21-33. 
The Economist Intelligence Unit's. 2018. "Democracy Index". https://infographics.economist. com/2018/DemocracyIndex/ [Accessed: 11 August 2018].

Gdula, Maciej. 2018. Nowy autorytaryzm. Warszawa: Wydawnictwo Krytyki Politycznej.

Halmai, Gábor. 2014. "An Illiberal Constitutional System in the Middle of Europe". European Yearbook on Human Rights 14: 497-514.

Joerges, Christian. Christian Kreuder-Sonnen. 2017. "European Studies and the European Crisis: Legal and Political Science between Critique and Complacency". European Law Journal 23(1-2): 118-139.

Kelemen, R. Daniel. 2017. "Europe's Other Democratic Deficit: National Authoritarianism in Europe's Democratic Union". Government and Opposition 52(2): 211-238.

Levi, Niel. Michael Rothberg, 2018. "Memory Studies in a Moment of Danger: Fascism, Postfascism, and the Contemporary Political Imaginary". Memory Studies 11(3): 355-367.

Mańko, Rafał. Cosmin Cercel. Adam Sulikowski. 2016. "Introduction. Law and Critique in Central Europe: Laying the Cornerstone". In Law and Critique in Central Europe. Questioning the Past, Resisting the Present. 1-15. Edited by Rafał Mańko, Cosmin Cercel, Adam Sulikowski. Oxford: Counterpress.

Müller, Jan-Werner. 2016. What Is Populism? Princeton: Princeton University Press.

Oliver, Peter. Justine Stefanelli. 2016. "Strengthening the Rule of Law in the EU: The Council's Inaction". Journal of Common Market Studies 54(5): 1075-1084.

Palombella, Gianluigi. 2018. "Illiberal, Democratic and Non-Arbitrary? Epicentre and Circumstances of a Rule of Law Crisis". Hague Journal of the Rule of Law 10: 5-19.

Pech, Laurent. Kim Lane Scheppele. 2017. "Illiberalism Within: Rule of Law Backsliding in the EU”. Cambridge Yearbook of European Legal Studies 19: 3-47.

Pinelli, Cesare. 2011. "The Populist Challenge to Constitutional Democracy". European Constitutional Law Review 7: 5-16.

Poulantzas, Nicos. 1979. Fascism and Dictatorship. The Third International and the Problem of Fascism. London: Verso.

Saward, Michael. 2010. The Representative Claim. Oxford: Oxford University Press.

Scharpf, Fritz. 2015. "After the Crash: A perspective on Multilevel European Democracy". European Law Journal 21(3): 384-403.

Scheppele, Kim Lane. 2015. “Understanding Hungary's Constitutional Revolution”. In Constitutional Crisis in the European Constitutional Area. Theory, Law and Politics in Hungary and Romania. 111-124. Edited by Armin von Bogdandy, Pal Sonervend. München: Beck, Hart \& Nomos.

Sólyom, László. 2015. “The Rise and Decline of Constitutional Culture in Hungary”. In Constitutional Crisis in the European Constitutional Area. Theory, Law and Politics in Hungary and Romania. 5-31. Edited by Armin von Bogdandy, Pal Sonerven. München: Beck, Hart \& Nomos.

Sulikowski, Adam. 2012. Konstytucjonalizm a nowoczesność. Dyskurs konstytucyjny wobec tryumfu i kryzysu moderny. Wrocław: Wydawnictwo Uniwersytetu Wrocławskiego. 